\title{
Microbial Causes of Summer Mortality in Farmed Fish in Egypt
}

\author{
M.E. Enany *, N.H. Eidaroos Abou ELAtta *, M.**, N.M, Eltamimy *** \\ *Bacteriology, Immunology and Mycology Department, Faculty of \\ Veterinary Medicine, Suez Canal University. \\ ${ }^{*}{ }^{*}$ central laboratory for Aquaculture Research. Abbassa, Abou Hammad, \\ Sharkia, ***Free veterinarian
}

\begin{abstract}
Bacterial diseases are responsible for sever mortalities and morbidities in cultured Nile tilapia in Egypt in various fresh water fish farms and the increase of water temperature in summer has a significant effect on mortalities. A total number of 100 clinically diseased Nile Tilapia (Orechromis niloticus) were collected alive randomly from Abbassa, Elsharkia (Central Laboratory for Aquaculture Research) Egypt, to identify the bacterial pathogens affect that fish. Samples were isolated from liver, kidney, spleen, eye, ulcer and brain. The isolated fish pathogens were identified as Aeromonas hydrophila, Ps.fluorescense, Ps.putida and V.cholera by their morphological characteristics, biochemical tests, Antibiotic sensitivity test and polymerase chain reaction test as a confirmatory results. The results of Anmicrobial sensitivity of the isolated strains revealed that tetracycline (TE30), oxytetracycline (T30), nalidixic acid (NA30), norfloxacin (NOR10) and sulpha-Trimethoprim (SXT25) were the drugs of choice against Aeromonas hydrophila, tetracycline (TE30),oxytetracycline (T30), tobramicin (TOB10) and kanamycin (K30) were the drugs of choice against Pseudomonas flurocence, streptomycin (S10), tobramicin (TOB10), and kanamycin (K30) were the drugs of choice against Pseudomonas putida While oxytetracycline (T30) and nalidixic acid (NA30) were the drugs of choice against Vibrio cholera. The results of Polymerase Chain Reaction (PCR) confirmed the antibiotic sensitivity test results and also confirmed the incidence of Aeromonas hydrophila, Pseudomonas flurocence and Vibrio cholera in the infected fish.
\end{abstract}

\section{Introduction}

Fish represents a vital source of food for people also fish has economic importance. It is necessary for the financial and nutritional health of human (Tidwell and Allan, 2001).

Egypt is the biggest aquaculture reproducer in Africa and eighth largest internationally in 2011, Fish 
utilization in Egypt ascended from $8.5 \mathrm{~kg}$ to $15.4 \mathrm{~kg} /$ individual $/$ year among 1996 and 2008. Nile Tilapia (Oreochromis niloticus) is the most cultured fish in Egypt. Unfortunately, intensive fish farming is associated with a number of challenges including diseases, which demotivate farmers due to the economical losses (ELTholth et al., 2015).

Cultured fish diseases have a negative effect on the achievement maximum capacity in fish farming. Bacterial pathogens are the most critical problem in Tilapia production responsible for $\mathbf{8 0 \%}$ of fish mortalities. (EL-Refaee, 2004). Even though Tilapia is more resistant to a lot of pathogenic microorganisms, outbreaks of Aeromonas infection had been reported in cultured tilapia in various aquaculture farms Yambot (1998).

Bacterial diseases are responsible for sever mortalities and morbidities in 2001 in cultured Nile tilapia in Egypt in various fresh water fish farms. Laboratory studies appeared the existence of A.hydrophila in $70 \%$ of examined fish (Aly, 2013).

The proper management of fish health begins with prevention of disease better than treatment (Faruk et al. ,2004).

\section{Material and Method:}

Fish:

A total number of 100 clinically infected Nile Tilapia were collected from Abbassa, Elsharkia (Central
Laboratory for Aquaculture Research) Egypt for bacteriological examination. Each individual sample was placed separately into sealed sterile plastic bag, thoroughly identified and delivered to the laboratory in icebox.

\section{Bacteriological examination:}

A total number of 300 samples were collected from (fins, tails, skin ulcers, liver, kidney, spleen, brain and eyes) under complete aseptic conditions. The samples were inoculated into Tryptic soya broth and incubated at $29-30^{\circ} \mathrm{c}$ for $18-24$ hours as described by $\boldsymbol{A P H A}$ (1992), then subcultured on the selective media (Thiosulphate citrate bile salt sucrose agar, Aeromonas selective agar base and pseudomonas selective agar base) and incubated at $29-30^{\circ} \mathrm{c}$ for $24-48$ hours. The suspected pure colonies were picked up and streaked onto the same specific media for further purification and isolated pure colonies were transferred into nutrient agar slant for further identification. The bacterial isolates were identified according to Macfidden (1976) and Lopez Romalde et al. (2003).

\section{Antimicrobial sensitivity test:}

The antimicrobial sensitivity test of the common isolated bacterial pathogens (A.hydrophila, P.fluorescens, P.putida and V.alginolyticus) were performed by disc diffusion test according to Bauer et al. (1966) and interpreted according to NCCLS/CLSI (2007).The antibiotic discs were 
Streptomycin,

oxytetracycline,

nalidixic acid,

kanamycine,

novobiocin, neomycin, norfloxacin and sulpha-Trimethoprim.

\section{Pathogenicity test:}

Total number of 50 Nile Tilapia fish were collected alive an apparently healthy from private hatcheries in El Abbassa, Sharquia Governorate with an average body weight $(25 \pm 5$ g.). They were tested for susceptibility to experimental infection with A.hydrophila, Ps.fluorescens, Ps.putida and V.cholera isolated from naturally infected Nile Tilapia. All experimental fish were fed with commercial ration at rate of $5 \%$ body weight per day. Fish were divided into 5 groups (G1,G2,G3,G4 and G5 as control ) 10 fish per group. (and the inocula of bacterial strains were prepared for I/P injection according to Austin and Austin (1999).

The injected dose of A.hydrophila and Ps.fluorescens was $(0.2 \mathrm{ml}$ of $3 \mathrm{x} 10^{7} \mathrm{Cfu}$ ) while the dose in V.cholera $\left(0.2 \mathrm{ml}\right.$ of $\left.2.5 \times 10^{8} \mathrm{Cfu}\right)$ according to (Austin and Austin 2007) and the control group injected with $0.2 \mathrm{ml}$ of sterile saline.
All experimental injected fish were observed daily for 10 days to record any clinical or abnormal signs and the daily mortalities. Also postmortem examination was performed on dead fish to record gross lesions and re-isolation of injected pathogen.

\section{Polymerase Chain reaction:}

Polymerase Chain reaction were performed for accurate identification of Aeromonas hydrophila, Pseudomonas spp. and Vibrio cholera and for detection of resistant genes and the prevalence of virulence genes of $A$. hydrophila the oligonucleotide primers sequences of different genes Table (1). DNA extraction had been done by following manufacturer's instructions of QIAamp DNA mini kit. Temperature and time conditions of the primers during PCR are shown in Table (2) according to Machado et al. (2013). PCR products were electrophorized using $1 \%$ agarose gel using Gel casting apparatus (Biometra). The gel was photographed by a gel documentation system and the data analyzed through computer software according to Sambrook et al. (1989). 
Table (1): Oligonucleotide primers sequences.

\begin{tabular}{|c|c|c|c|c|}
\hline genes & Gene & $\begin{array}{l}\text { Sequence } \\
5 '-3\end{array}$ & $\begin{array}{c}\text { Amplified } \\
\text { product } \\
\text { (bp) }\end{array}$ & Reference \\
\hline \multirow[t]{2}{*}{ P. fluorescens } & \multirow[t]{2}{*}{ 16SrDNA } & F: TGCATTCAAAACTGACTG & \multirow[b]{2}{*}{850} & \multirow{2}{*}{$\begin{array}{c}\text { Machado et } \\
\text { al. } 2013\end{array}$} \\
\hline & & R: AATCACACCGTGGTAACCG & & \\
\hline \multirow{2}{*}{$\begin{array}{l}\text { Pseudomonas } \\
\text { species }\end{array}$} & \multirow[t]{2}{*}{ 16SrDNA } & F: GACGGGTGAGTAATGCCTA & \multirow{2}{*}{618} & \multirow{2}{*}{$\begin{array}{l}\text { Spilker } e t \\
\text { al., } 2004\end{array}$} \\
\hline & & R: CACTGGTGTTCCTTCCTATA & & \\
\hline \multirow[t]{2}{*}{ A. hydrophila } & \multirow[t]{2}{*}{ 16Sr RNA } & F: GAAAGGTTGATGCCTAATACGTA & \multirow{2}{*}{625} & \multirow{2}{*}{$\begin{array}{c}\text { Gordon } e t \\
\text { al., } 2007\end{array}$} \\
\hline & & R: CGTGCTGGCAACAAAGGACAG & & \\
\hline \multirow[t]{2}{*}{ V. cholera } & \multirow[t]{2}{*}{ ompW } & F: CACCAAGAAGGTGACTTTATTGTG & \multirow{2}{*}{304} & \multirow{2}{*}{$\begin{array}{c}\text { De Menezes } \\
\text { et al., } 2014\end{array}$} \\
\hline & & R: GGTTTGTCGAATTAGCTTCACC & & \\
\hline \multirow{2}{*}{$\begin{array}{l}\text { Pseudomonas } \\
\text { species }\end{array}$} & \multirow[t]{2}{*}{ kan } & F: GTGTTTATGGCTCTCTTGGTC & \multirow{2}{*}{621} & \multirow{2}{*}{$\begin{array}{c}\text { Frana et al., } \\
2001\end{array}$} \\
\hline & & R: CCGTGTCGTTCTGTCCACTCC & & \\
\hline \multirow[t]{2}{*}{ All } & \multirow[t]{2}{*}{$\operatorname{tet} \mathrm{A}(A)$} & F: GGTTCACTCGAACGACGTCA & \multirow{2}{*}{576} & \multirow{4}{*}{$\begin{array}{c}\text { Randall et } \\
\text { al. } 2004\end{array}$} \\
\hline & & R: CTGTCCGACAAGTTGCATGA & & \\
\hline \multirow{2}{*}{$\begin{array}{l}\text { V. cholera, } P . \\
\text { fluorescens }\end{array}$} & \multirow[t]{2}{*}{ aadl } & F: TATCAGAGGTAGTTGGCGTCAT & \multirow{2}{*}{484} & \\
\hline & & R: GTTCCATAGCGTTAAGGTTTCATT & & \\
\hline \multirow[t]{6}{*}{ A.hydrophila } & \multirow[t]{2}{*}{$\operatorname{aadB}$} & F: GAGCGAAATCTGCCGCTCTGG & \multirow{2}{*}{319} & \multirow{2}{*}{$\begin{array}{c}\text { Frana } \text { et al., } \\
2001\end{array}$} \\
\hline & & R: CTGTTACAACGGACTGGCCGC & & \\
\hline & \multirow{2}{*}{$\begin{array}{l}\text { Haemolysin } \\
(\text { hly })\end{array}$} & F: CTATGAAAAAACTAAAAATAACTG & \multirow{2}{*}{1500} & \multirow{2}{*}{$\begin{array}{c}\text { Yousr } \text { et al., } \\
2007\end{array}$} \\
\hline & & R: CAGTATAAGTGGGGAAATGGAAAG & & \\
\hline & \multirow{2}{*}{$\begin{array}{c}\text { Aerolysin } \\
\text { (Aero) }\end{array}$} & F: CACAGCCAATATGTCGGTGAAG & \multirow{2}{*}{326} & Singh et al., \\
\hline & & R: GTCACCTTCTCGCTCAGGC & & 2008 \\
\hline
\end{tabular}

Table (2): Cycling conditions of the different primers during $c P C R$

\begin{tabular}{|c|c|c|c|c|c|c|c|}
\hline \multirow[t]{2}{*}{ genes } & \multirow[t]{2}{*}{ Gene } & \multirow{2}{*}{$\begin{array}{c}\text { Primary } \\
\text { denaturation }\end{array}$} & \multicolumn{4}{|c|}{ Amplification } & \multirow{2}{*}{$\begin{array}{c}\text { Final } \\
\text { extension }\end{array}$} \\
\hline & & & $\begin{array}{c}\text { Secondary } \\
\text { denaturation }\end{array}$ & Annealing & Extension & $\begin{array}{c}\text { No. } \\
\text { of } \\
\text { cycles }\end{array}$ & \\
\hline $\begin{array}{c}P . \\
\text { fluorescens }\end{array}$ & $16 S \mathrm{rDNA}$ & $\begin{array}{c}94^{\circ} \mathrm{C} \\
5 \mathrm{~min} .\end{array}$ & $\begin{array}{c}94^{\circ} \mathrm{C} \\
30 \mathrm{sec} .\end{array}$ & $\begin{array}{c}48^{\circ} \mathrm{C} \\
40 \mathrm{sec} .\end{array}$ & $\begin{array}{l}72^{\circ} \mathrm{C} \\
1 \mathrm{~min} .\end{array}$ & 35 & $\begin{array}{c}72^{\circ} \mathrm{C} \\
10 \mathrm{~min} .\end{array}$ \\
\hline $\begin{array}{c}\text { Pseudomonas } \\
\text { species }\end{array}$ & $16 S r D N A$ & $\begin{array}{c}94^{\circ} \mathrm{C} \\
5 \mathrm{~min} .\end{array}$ & $\begin{array}{c}94^{\circ} \mathrm{C} \\
30 \mathrm{sec} .\end{array}$ & $\begin{array}{c}57^{\circ} \mathrm{C} \\
1 \mathrm{~min} .\end{array}$ & $\begin{array}{l}72^{\circ} \mathrm{C} \\
1 \mathrm{~min} .\end{array}$ & 35 & $\begin{array}{c}72^{\circ} \mathrm{C} \\
10 \mathrm{~min} .\end{array}$ \\
\hline A. hydrophila & $16 S r R N A$ & $\begin{array}{l}94^{\circ} \mathrm{C} \\
5 \mathrm{~min} .\end{array}$ & $\begin{array}{c}94^{\circ} \mathrm{C} \\
30 \mathrm{sec} .\end{array}$ & $\begin{array}{c}50^{\circ} \mathrm{C} \\
40 \mathrm{sec} .\end{array}$ & $\begin{array}{r}72^{\circ} \mathrm{C} \\
45 \mathrm{sec} .\end{array}$ & 35 & $\begin{array}{c}72^{\circ} \mathrm{C} \\
10 \mathrm{~min} .\end{array}$ \\
\hline V. cholera & ompW & $\begin{array}{l}94^{\circ} \mathrm{C} \\
5 \mathrm{~min} .\end{array}$ & $\begin{array}{c}94^{\circ} \mathrm{C} \\
30 \mathrm{sec} .\end{array}$ & $\begin{array}{c}59^{\circ} \mathrm{C} \\
30 \mathrm{sec} .\end{array}$ & $\begin{array}{c}72^{\circ} \mathrm{C} \\
30 \mathrm{sec} .\end{array}$ & 35 & $\begin{array}{l}72^{\circ} \mathrm{C} \\
7 \mathrm{~min} .\end{array}$ \\
\hline $\begin{array}{c}\text { Pseudomonas } \\
\text { species }\end{array}$ & kan & $\begin{array}{l}94^{\circ} \mathrm{C} \\
5 \mathrm{~min} .\end{array}$ & $\begin{array}{c}94^{\circ} \mathrm{C} \\
30 \mathrm{sec} .\end{array}$ & $\begin{array}{c}54^{\circ} \mathrm{C} \\
40 \mathrm{sec} .\end{array}$ & $\begin{array}{r}72^{\circ} \mathrm{C} \\
45 \mathrm{sec} .\end{array}$ & 35 & $\begin{array}{c}72^{\circ} \mathrm{C} \\
10 \mathrm{~min} .\end{array}$ \\
\hline All & $\operatorname{Tet} A(A)$ & $\begin{array}{l}94^{\circ} \mathrm{C} \\
5 \mathrm{~min} .\end{array}$ & $\begin{array}{c}94^{\circ} \mathrm{C} \\
30 \mathrm{sec} .\end{array}$ & $\begin{array}{c}50^{\circ} \mathrm{C} \\
40 \mathrm{sec} .\end{array}$ & $\begin{array}{c}72^{\circ} \mathrm{C} \\
45 \mathrm{sec} .\end{array}$ & 35 & $\begin{array}{c}72^{\circ} \mathrm{C} \\
10 \mathrm{~min} .\end{array}$ \\
\hline $\begin{array}{l}\text { V. cholera, } P . \\
\text { fluorescens }\end{array}$ & Aadal & $\begin{array}{l}94^{\circ} \mathrm{C} \\
5 \mathrm{~min} .\end{array}$ & $\begin{array}{c}94^{\circ} \mathrm{C} \\
30 \mathrm{sec} .\end{array}$ & $\begin{array}{c}54^{\circ} \mathrm{C} \\
40 \mathrm{sec} .\end{array}$ & $\begin{array}{c}72^{\circ} \mathrm{C} \\
45 \mathrm{sec} .\end{array}$ & 35 & $\begin{array}{c}72^{\circ} \mathrm{C} \\
10 \mathrm{~min} .\end{array}$ \\
\hline \multirow[t]{3}{*}{ A. hydrophila } & $A a d a B$ & $\begin{array}{l}94^{\circ} \mathrm{C} \\
5 \mathrm{~min} .\end{array}$ & $\begin{array}{c}94^{\circ} \mathrm{C} \\
30 \mathrm{sec} .\end{array}$ & $\begin{array}{c}58^{\circ} \mathrm{C} \\
40 \mathrm{sec} .\end{array}$ & $\begin{array}{c}72^{\circ} \mathrm{C} \\
40 \mathrm{sec} .\end{array}$ & 35 & $\begin{array}{c}72^{\circ} \mathrm{C} \\
10 \mathrm{~min} .\end{array}$ \\
\hline & $\begin{array}{c}\text { Haemolysin } \\
(h l y)\end{array}$ & $\begin{array}{c}94^{\circ} \mathrm{C} \\
5 \mathrm{~min} .\end{array}$ & $\begin{array}{c}94^{\circ} \mathrm{C} \\
30 \mathrm{sec} .\end{array}$ & $\begin{array}{c}55^{\circ} \mathrm{C} \\
1 \mathrm{~min} .\end{array}$ & $\begin{array}{c}72^{\circ} \mathrm{C} \\
1.5 \mathrm{~min} .\end{array}$ & 35 & $\begin{array}{c}72^{\circ} \mathrm{C} \\
12 \mathrm{~min} .\end{array}$ \\
\hline & $\begin{array}{c}\text { Aerolysin } \\
(\text { Aero })\end{array}$ & $\begin{array}{c}94^{\circ} \mathrm{C} \\
5 \mathrm{~min} .\end{array}$ & $\begin{array}{c}94^{\circ} \mathrm{C} \\
30 \mathrm{sec} .\end{array}$ & $\begin{array}{c}52^{\circ} \mathrm{C} \\
40 \mathrm{sec} .\end{array}$ & $\begin{array}{c}72^{\circ} \mathrm{C} \\
40 \mathrm{sec} .\end{array}$ & 35 & $\begin{array}{c}72^{\circ} \mathrm{C} \\
10 \mathrm{~min} .\end{array}$ \\
\hline
\end{tabular}


Results and Discussion:

A total number of 300 samples were collected from 100 clinically infected fishes. The bacteriological examination of samples that were collected during summer (2017) give rise to 160 bacterial isolates that were differentiated into A.hydrophila, P.flurocence, P.putida and V.cholera with the percentage of $(50,21.87,15.62$ and 12.5) respectively (table 3 ), while in winter (2018) A.hydrophila, P.flurocence and V.cholera were recovered from 100 samples with percentage of $(50,37,13 \%)$ respectively (table 4). A total number of 40 samples were collected in summer (2018) where A.hydrophila isolated with percentage of $47.22 \%$, P.flurocence $22.22 \%$, P.putida (13.88\%) and V.cholera (16.66\%) (table 5).

The results of seasonal prevalence of bacterial strains indicated that in summer the mortalities on naturally infected farmed fish was higher than that in winter.

The present study showed that Aeromonas spp. has been isolated from ulcerated tilapia fish in different seasons by $70 \%$ in summer and $50 \%$ in winter, this result is similar to McGarey et al. (1991) and Maimona and Sabiel (2015). On contrary, concerning $P$. fluorescence, in previous study in Egypt it was isolated from O.niloticus with skin ulcers in summer by $40 \%$ and in winter $37 \%$. While Maimona and Sabiel
(2015) in Sudan, didn't find Pseudomonas spp. in similar cases. This difference may be attributed to difference in seasonal or temperature variations during which the samples were collected, disagreement on these results can be explained as Pseudomonads prefer winter period as recorded by Castro-Escarpulli et al. (2003).

The results of pathogenisty test revealed that the mortality rate of the experimental injected fish by dose of Aeromonas hydrophila (0.2 $\mathrm{ml}$ of $3 \times 10^{7} \mathrm{Cfu}$ ) was $90 \%$, the injected fish by dose of Pseudomonas flurosence $(0.2 \mathrm{ml}$ of $3 \times 10^{7} \mathrm{Cfu}$ ) was $80 \%$, Pseudomonas putida injected to healthy fish by dose $\left(0.2 \mathrm{ml}\right.$ of $\left.3 \mathrm{x} 10^{7} \mathrm{Cfu}\right)$ was $70 \%$ while that injected by dose of Vibrio cholera $(0.2 \mathrm{ml}$ of $3 \mathrm{x}$ $10^{7} \mathrm{Cfu}$ ) was $30 \%$.as shown in table (6) Aeromonashydrophila causes the highest mortality rate.

The results of Antibiotic sensitivity of the isolated strains revealed that tetracycline (TE30), oxytetracycline (T30), nalidixic acid (NA30), norfloxacin (NOR10) and sulphaTrimethoprim (SXT25) were the drugs of choice against Aeromonas hydrophila, tetracycline (TE30), oxytetracycline (T30), tobramicin (TOB10) and kanamycin (K30) were the drug of choice against Pseudomonas

flurocence, Streptomycin (S10), tobramicin (TOB10), and kanamycin (K30) were the drugs of choice against Pseudomonas putida While 
oxytetracycline (T30) and nalidixic acid (NA30) were the drugs of choice against Vibrio cholera.

These results agreed with Kaznowski (1998), Salama (1999), Abou El-Atta and El-Tantawy (2008) but the results were partially agreed with Sarma et al., (1990) who described that ampicillin, oxytetracycline, streptomycin and nalidixic acid were the most effective against Aeromonas hydrophila, Megahed (2002) who recorded chloramphenicol and Nalidixic acid were the most effective drugs against Aeromonas hydrophila and The results were disagreed with Hettiarachchi and Cheong (1994) who reported that all Aeromonas hydrophila were resistant to Tetracycline, Penicillin and Streptomycin.

The present results supported by gentamicin was effective drug against Pseudomonas spp. Khalil et al. (2010), ciprofloxacin was more effective antibiotic against Pseudomonas spp. than other antibiotics Mesaros et al. (2007). In a study by Enany et al. (2011) concluded that $P$. fluorescens was sensitive to Ciprofloxacin and rifampicine while resist amoxicillin and erythromycin.
In a recent study on Pseudomonas spp. by Younes et al. (2015), the most of isolates were sensitive to Choloramphenicol, Kanamycin and Gentamicin while resistant to Amoxicillin and Ampicillin. $P$. putida was the only Pseudomonas spp. that was sensitive to Erythromycin and this support the present result. In addition, this result is nearly in consonant with Eissa et al., (2010) who concluded that $P$. putida and $P$. anguilliseptica were sensitive to Erythromycin. The results of Polymerase Chain Reaction (PCR) confirmed the incidence of A.hydrophila, P.flurocence, P.putida and V.cholera (nonpathogenic to fish) in the infected fish and also confirmed the results of antimicrobial sensitivity test where the examined isolates of these microorganisms were carrier to the resistant and sensitive gene that observed in the sensitivity test. (Fig. 1, 2, 3, 4, 5 and 6)

The most prevalent organism that cause summer mortalities was $A$. hydrophila so the detection of virulence genes was very important for confirmation of the results. The result of theprevalence of virulence gene (aerolysin and haemolysin) is shown in Fig.

(3). 
Table (3): The isolated bacterial strains from the collected fish in summer (2017):

\begin{tabular}{|l|l|l|l|c|c|}
\hline Season & $\begin{array}{l}\text { Total } \\
\text { fish }\end{array}$ & $\begin{array}{l}\text { Total } \\
\text { isolates }\end{array}$ & Isolated strains & $\begin{array}{l}\text { Total } \\
\text { isolates }\end{array}$ & $\begin{array}{l}\text { Percentage } \\
\text { \% }\end{array}$ \\
\hline \multirow{3}{*}{$\begin{array}{l}\text { Summer } \\
(2017)\end{array}$} & \multirow{3}{*}{35} & \multirow{2}{*}{$\mathbf{1 6 0}$} & Aeromonas hydrophila & $\mathbf{8 0}$ & $\mathbf{5 0}$ \\
\cline { 4 - 6 } & & & Pseudomonas fluorensce & $\mathbf{3 5}$ & $\mathbf{2 1 . 8 7}$ \\
\cline { 4 - 6 } & & & Pseudomonas putida & $\mathbf{2 5}$ & $\mathbf{1 5 . 6 2}$ \\
\cline { 3 - 5 } & & Vibrio cholera & $\mathbf{2 0}$ & $\mathbf{1 2 . 5}$ \\
\hline
\end{tabular}

Table (4): The isolated bacterial strains from the collected fish in Winter (2018):

\begin{tabular}{|l|l|l|l|l|c|}
\hline Season & $\begin{array}{l}\text { Total } \\
\text { fish }\end{array}$ & $\begin{array}{l}\text { Total } \\
\text { isolates }\end{array}$ & Isolated strains & $\begin{array}{l}\text { Total } \\
\text { isolates }\end{array}$ & $\begin{array}{l}\text { Percentage } \\
\mathbf{\%}\end{array}$ \\
\hline \multirow{2}{*}{$\begin{array}{l}\text { Winter } \\
\mathbf{2 0 1 8}\end{array}$} & \multirow{2}{*}{$\mathbf{2 5}$} & \multirow{2}{*}{$\mathbf{1 0 0}$} & Aeromonashydrophila & $\mathbf{5 0}$ & $\mathbf{5 0}$ \\
\cline { 4 - 6 } & & & Pseudomonas fluorensce & $\mathbf{3 7}$ & $\mathbf{3 7}$ \\
\cline { 4 - 6 } & & & Vibrio cholera & $\mathbf{1 3}$ & $\mathbf{1 3}$ \\
\hline
\end{tabular}

Table (5): The isolated bacterial strains from the collected fish in Summer (2018):

\begin{tabular}{|l|l|l|l|c|c|}
\hline Season & $\begin{array}{l}\text { Total } \\
\text { fish }\end{array}$ & $\begin{array}{l}\text { Total } \\
\text { isolates }\end{array}$ & Isolated strains & $\begin{array}{l}\text { Total } \\
\text { isolates }\end{array}$ & $\begin{array}{l}\text { Percentage } \\
\text { \% }\end{array}$ \\
\hline \multirow{3}{*}{$\begin{array}{l}\text { Summer } \\
(2018)\end{array}$} & \multirow{2}{*}{40} & \multirow{2}{*}{$\mathbf{1 8 0}$} & Aeromonashydrophila & $\mathbf{8 5}$ & $\mathbf{4 7 . 2 2}$ \\
\cline { 4 - 6 } & & & Pseudomonas fluorensce & $\mathbf{4 0}$ & $\mathbf{2 2 . 2 2}$ \\
\cline { 4 - 6 } & & & Pseudomonas putida & $\mathbf{2 5}$ & $\mathbf{1 3 . 8 8}$ \\
\cline { 3 - 5 } & & Vibrio cholera & $\mathbf{3 0}$ & $\mathbf{1 6 . 6 6}$ \\
\hline
\end{tabular}

Table (6) Mortality rate of experimentally infected (Oreochromisniloticus) with isolated strains:

\begin{tabular}{|c|c|c|c|c|c|c|c|c|c|c|c|c|}
\hline \multirow{2}{*}{ Groups } & \multirow{2}{*}{$\begin{array}{l}\text { No. } \\
\text { Fish }\end{array}$} & \multirow{2}{*}{$\begin{array}{c}\text { Dose of isolated } \\
\text { strains }\end{array}$} & \multirow{2}{*}{$\begin{array}{l}\text { Rout of } \\
\text { injection }\end{array}$} & \multicolumn{7}{|c|}{ Dead fish post injection } & \multirow{2}{*}{$\begin{array}{c}\text { No. of } \\
\text { dead } \\
\text { fish }\end{array}$} & \multirow{2}{*}{$\begin{array}{c}\text { Mortality } \\
\text { rate }\end{array}$} \\
\hline & & & & 1 & 2 & 3 & 4 & 5 & 6 & 7 & & \\
\hline 1 & 10 & $\begin{array}{c}\text { A.hydrophila } \\
\left(0.2 \mathrm{ml} \text { of } 3 \times 10^{7} \mathrm{Cfu}\right)\end{array}$ & $\mathrm{I} / \mathrm{P}$ & 3 & 2 & 3 & 1 & 0 & 0 & 0 & 9 & $90 \%$ \\
\hline 2 & 10 & $\begin{array}{c}\text { P.fluroscense } \\
\left(0.2 \mathrm{ml} \text { of } 3 \times 10^{7} \mathrm{Cfu}\right)\end{array}$ & $\mathrm{I} / \mathrm{P}$ & 2 & 2 & 3 & 1 & 0 & 0 & 0 & 8 & $80 \%$ \\
\hline 3 & 10 & $\begin{array}{c}\text { P.putida } \\
\left(0.2 \mathrm{ml} \text { of } 3 \times 10^{7} \mathrm{Cfu}\right) \\
\end{array}$ & $\mathrm{I} / \mathrm{P}$ & 0 & 2 & 2 & 3 & 0 & 0 & 0 & 7 & $70 \%$ \\
\hline 4 & 10 & $\begin{array}{c}\text { V.cholera } \\
\left(0.2 \mathrm{ml} \text { of } 2.5 \times 10^{8} \mathrm{Cfu}\right)\end{array}$ & $\mathrm{I} / \mathrm{P}$ & 0 & 0 & 0 & 1 & 1 & 1 & 0 & 3 & $30 \%$ \\
\hline 5 & 10 & $0.2 \mathrm{ml}$ sterile solution & $\mathrm{I} / \mathrm{P}$ & - & - & - & - & - & - & - & 0 & $0 \%$ \\
\hline
\end{tabular}




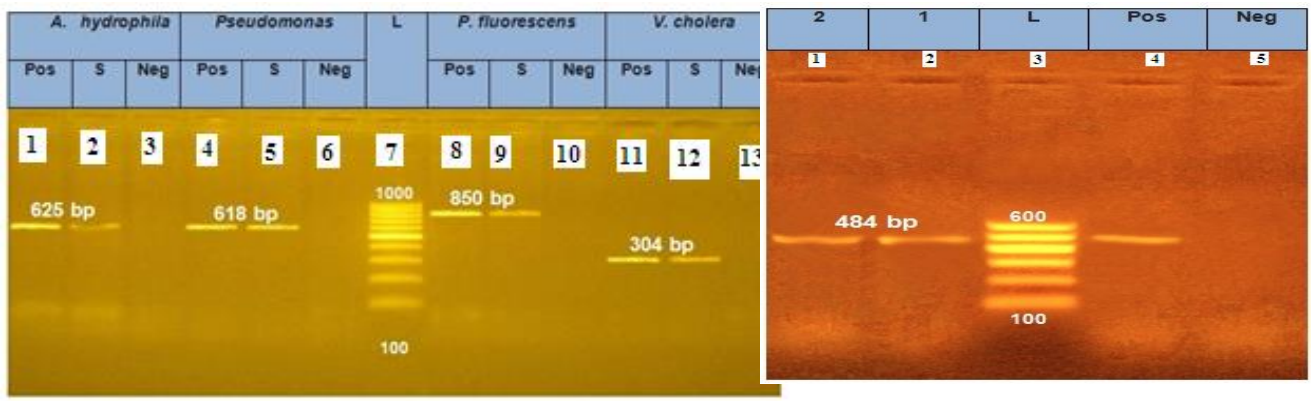

Figure (1) Gel electrophoresis of PCR amplification of the identification of Pseudomonas spp by 16SrDNA gene, Aeromonas hydrophila by 16SrRNA gene and Vibrio cholera by omp $\mathrm{W}$ gene showing positive amplification in A.hydrophila at 625 bp products at lane 2, positive control (lane 1) and negative control (lane 3), Pseudomonas putida at 618 bp products at lane 5 , positive control (lane 4) and negative control (lane 6), P.fluorescens at $850 \mathrm{bp}$ at lane 9, positive control (lane 8) and negative control (lane 10) and V.cholera at $304 \mathrm{bp}$ at lane 12, positive control (lane11) negative control (lane 13), respectively. Lane 7 (L) is 100 bp DNA marker.

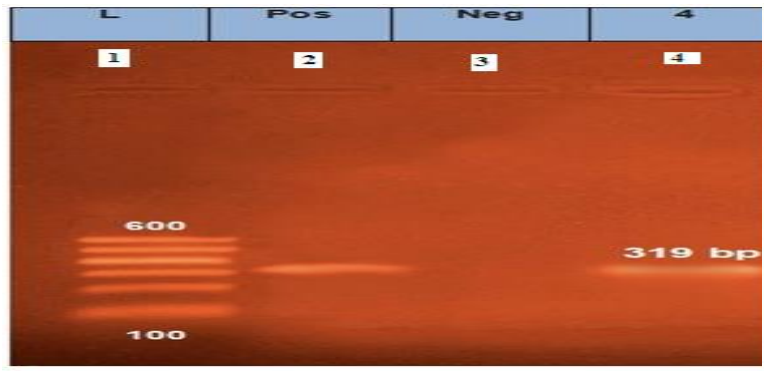

Figure (3). Gel electrophoresis of PCR amplification of the resistance gene $(a a d B)$ in Aeromonas hydrophila, showing positive amplification at $319 \mathrm{bp}$ products at lane 4, positive control (lane 2) and negative control (lane 3), respectably. Lane L is 100 bp DNA marker.
Figure (2).Gel electrophoresis of PCR amplification of the resistance gene (aada1) in $V$. cholera and $P$. fluorescens, showing positive amplification at $484 \mathrm{bp}$ products at lanes 1-2, positive control (lane 4) and negative control (lane 5), respectively. Lane 3 (L) is 100 bp DNA marker.

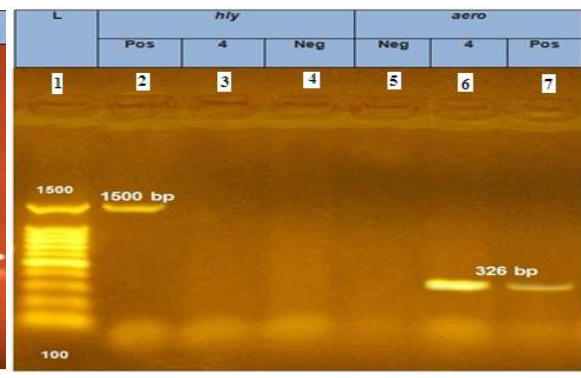

Figure (4). Gel electrophoresis of PCR amplification of the virulence gene (Haemolysin $(h l y)$ ) in Aeromonas hydrophila, showing no amplification at lane 3, positive control (lane 2) and negative control (lane 4), respectively. Lane $1(\mathrm{~L})$ is 100 bp DNA marker. Lane 6 showing positive amplification of $326 \mathrm{bp}$ products of Aerolysin (Aero) gene. And positive control (lane 7) and negative control (lane 5). 

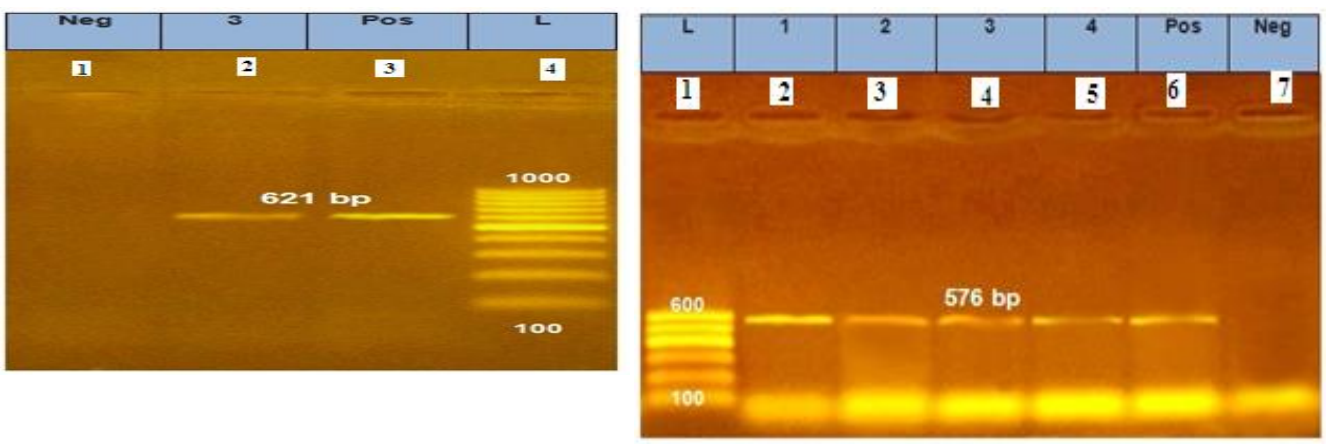

Figure (5). Gel electrophoresis of PCR amplification of the resistance gene (Kan) in Pseudomonas species, showing positive amplification at $621 \mathrm{bp}$ products at lane 2, positive control (lane 3 ) and negative control (lane 1), respectively. Lane 4 (L) is $100 \mathrm{bp}$ DNA marker.
Figure (6). Gel electrophoresis of PCR amplification of the resistance gene $(\operatorname{tet} A(A)$ in all species (Aeromomas hydrophila, Pseudomonas fluroscence, Pseudomonas putida and Vibrio cholera), showing positive amplification at 576 bp products at lane $1,2,3,4$ and 5, positive control (lane 6) and negative control (lane 7), respectively. Lane $1(\mathrm{~L})$ is 100 bp DNA marker.

\section{Refrences:}

Aly, S. M. (2013): A review of fish diseases in the Egyptian aquaculture sector: Working report.

Austin, B. and Austin, D.A (1999): Third edit. chapter 2 ; characteristics of the diseases. In the bacterial pathogens. Diseases of farmed and wild fish . Springer-Praxis, Praxis Publishing,Ltd. Chichester, Cuk.PP 13-15.

Austin, B., \& Austin, D. A. (2007): Characteristics of the diseases. Bacterial Fish Pathogens: Diseases of Farmed and Wild Fish, 1546.

APHA (1992): Compendium of methods for the microbiological examination of food. In C., Vanderzant, \& D. F. Splittstoesser. (Eds.). Washington, DC: American Public Health Association.

Bauer, A. W., Kirby, W. M., Sherris, J. C., \&Turck, M. (1966): Antibiotic Susceptibility Testing by a Standardized Single Disk Method. American Journal of Clinical Pathology, 45(4_ts), 493-496. doi:10.1093/ajcp/45.4_ts.493.

Castro-Escarpulli, G., Figueras, M. J., Aguilera-Arreola, G., Soler, L., Fernandez-Rendon, E., Aparicio, G. O., ...\& Chacon, M. R. (2003): Characterisation of Aeromonas spp. isolated from frozen fish intended for human consumption in Mexico. International Journal of Food Microbiology, 84(1), 41-49.

De Menezes,F.G.R.; Neves,S.D.; De Sousa, O.V.; Vila-Nova(2), Rodrigo Maggioni, C.MV.M.; Theophilo, G.N.D.; Hofer, E. and Vieira, R.H.S.D. (2014): Detection Of Virulence Genes In Environmental Strains Of Vibrio 
cholera From Estuaries In Northeastern Brazil. Rev. Inst. Med. Trop. Sao Paulo, 56(5):427-432.

Eissa, N. M. E., El-Ghiet, E. A., Shaheen, A. A., \&Abbass, A. (2010): Characterization of Pseudomonas species isolated from tilapia "Oreochromisniloticus" in Qaroun and Wadi-El-Rayan lakes, Egypt. Global Veterinaria, 5(2), 116-121.

EL-Banna N.I. (2014): Prevalence of common bacterial pathogens in marine fishes. M.V.Sc. Theses in Microbiology. Department of Bacteriology-Immunology-Mycology. Fac.Vet.Med. Suez Canal Uni.

El-Refaee, A.M.E. (2004) Streptococcus infection in freshwater fish. Master's Thesis, Faculty of Veterinary Medicine, Alexandria University, Egypt.

Eltholth, M., Fornace, K., Grace, D., Rushton, J., \&Häsler, B. (2015): Characterisation of production, marketing and consumption patterns of farmed tilapia in the Nile Delta of Egypt. Food Policy, 51, 131-143. doi: 10.1016/j.foodpol.2015.01.002.

Enany, M. E., Ibrahim, H. A. Abou EL Att. M. E. and El Adawy, M. M. (2011): Bacteriological and histopathological studies on some bacterial pathogens causing diseases in cultured Mugilcapito fish in Ismailia governorate. SCV MJ X VI (1) Pp 1-10.

Faruk, M. A. R., Alam, M. J., Sarker, M. M. R., \&Kabir, M. B. (2004): Status of fish disease and health management practices in rural freshwater aquaculture of Bangladesh. Pakistan J. Biol. Sci, 7(12), 2092-2098.

Finegold, S. M., \& Martin, S. (1982). Diagnostic Microbiology 6th ed the CV Mosby Company, St. Louis Tranto, London. Wiener TierarstilichMschr, 6, 233-236.

Frana, T. S., Carlson, S. A. \& Griffith, R. W. (2001). Relative distribution and conservation of genes encoding aminoglycoside-modifying enzymes in Salmonella enterica serotype Typhimurium phage type DT104. Applied and Environmental Microbiology 67, 445-8.

Gordon, L.; Giraud, E.; Ganiẽre, G.P.; Armand, F.; Bouju-Albert, A.; de la Cotte, N.; Mangion, C. and Le Bri, H. (2007): Antimicrobial resistance survey in a river receiving effluents from freshwater fish farms. Journal of Applied Microbiology; 102, 1167-1176.

Khalil, S. A.; Khalil, R. H.; Saad, T.T. and Safaa, M. H. (2010): Studies on Pseudomonas Septicemia among Cultured Oreochromisniloticus, Journal of the Arabian aquaculture society, vol. 5 no 1.

Lo'pez-Romalde , S.; Magariñ os, B.; Nu'ñez, S.; Toranzo, A.E. and Romalde, J.L. (2003): Phenotypic and genetic characterization of Pseudomonas anguilliseptica strains isolated from fish. J AquatAnim Health.2003a; 15:39-47.

MacFaddin, J.F. (1976): Biochemical tests for identification of medical 
bacteria the Williams and Wilkins Company, Baltimore, USA.

Machado, S.G.; Bazzolli, D.M.S. and Vanetti, M.C.D. (2013): Development of a PCR method for detecting proteolytic psychrotrophic bacteria in raw milk. International Dairy Journal 29 (2013) 8e14.

Maimona, S. and Y.A. Sabiel (2015): Detection of the causative agents of bacterial fish septicemia of tilapia and clarais in Khartoum state. Int. J. Recent Scient. Res., 6: 4374-4377.

McGarey, D.J., L. Milanesi, D.P. Foley, B. Reyes, Jr., L.C. Frye and D.V. Lim (1991): The role of motile Aeromonads in the fish disease, Ulcerative Disease Syndrome (UDS). Experientia, 47:441-444.

Mesaros, N.; Nordmann, P.; Roussel-Delvallez, M.; Van Eldere, J.; Glupczynski, Y.; Van Laethem, R. (2007): Pseudomonas aeruginosa resistance and therapeutic options at the turn of the new millennium. International Journal of Pharmacy and PharmaceuticalSciences.

NCCLS/CLSI (National Committee for Clinical Laboratory Standards/Clinical and Laboratory Standards Institute), (2007): CLSI document GP 18- Laboratory design; approved guideline. $2^{\text {nd }}$ ed. Clinical and Laboratory Standards Institute, Wayne (PA); 2007.

Randall, L.P.; Cooles, S.W.; Osborn, M.K.; Piddock, L.J.V. and Woodward, M.J. (2004). Antibiotic resistance genes, integrons and multiple antibiotic resistance in thirty-five serotypes of Salmonella entericaisolated from humans and animals in the UK. Journal of Antimicrobial Chemotherapy.53, 208-216.

Sambrook, J.; Fritscgh, E.F.; andMentiates (1989). Molecular coloning. A laboratory manual.Vol !., Cold spring Harbor Laboratotry press, New York.

Singh, V., Rathore, G., Kapoor, D., Mishra, B.N. and Lakra, W.S. (2008): Detection of aerolysin gene in Aeromonashydrophila isolated from fish and pond water. Indian J. Microbiol. (December 2008) 48:453-458.

Spilker, T., Coenye, T., Vandamme, P., \&LiPuma, J. J. (2004): PCRbased assay for differentiation of Pseudomonas aeruginosa from other Pseudomonas species recovered from cystic fibrosis patients. Journal of clinical microbiology, 42(5),2074-2079.

Tidwell, J. H., \& Allan, G. L. (2001): Fish as food: aquaculture's contribution: Ecological and economic impacts and contributions of fish farming and capture fisheries. EMBO reports, 2(11), 958-963.

Yambot, A. V. (1998): Isolation of Aeromonashydrophila from Oreochromisniloticus during fish disease outbreaks in the Philippines. Asian fisheries science, 10, 347-354.

Younes, A. M., Fares, M. O., Gaafar, A. Y., \& Mohamed, L. A. (2016): Isolation of Vibrio alginolyticus and Vibrio vulnificus Strains from Cultured 
Oreochromisniloticus Around Qarun Lake, Egypt. Global Veterinaria, 16(1), 01-05.

Yousr, A.H., Napis, S., Rusul, G.R.A. and Son, R. (2007): Detection of Aerolysin and Hemolysin Genes in Aeromonasspp.Isolated from Environmental and Shellfish Sources by Polymerase Chain Reaction. ASEAN Food Journal 14 (2): 115-122 (2007). 